\title{
AGRONOMIC PARAMETERS AND MORPHO-AGRONOMIC CHARACTERISTICS OF GENETICALLY MODIFIED MAIZE HYBRIDS COMPARED TO CONVENTIONAL MAIZE HYBRIDS
}

\author{
PARAMMETROS AGRÔNOMICOS E CARACTERÍSTICAS MORFOAGRONÔMICAS \\ DE HÍBRIDOS DE MILHO GENETICAMENTE MODIFICADOS COMPARADOS A \\ HÍBRIDOS DE MILHO CONVENCIONAIS
}

\author{
Leandro Nogueira RAMOS ${ }^{1}$; Nara Oliveira Silva SOUZA ${ }^{2}$; Michelle Souza VILELA ${ }^{2}$ \\ 1. Universidade de Brasília, Faculdade de Agronomia e Medicina Veterinária, Brasília, DF, Brasil. zleandro.ramos@gmail.com; 2. \\ Universidade de Brasília, Faculdade de Agronomia e Medicina Veterinária, Brasília, DF, Brasil. narasouza@unb.br.
}

\begin{abstract}
The objectives were to study the behavior of fifteen pre-commercial upland maize hybrids, analyze their agronomic performance regarding grain yield, and evaluate productivity components, as well as morpho-agronomic characteristics, in the Midwest Region of Brazil. Two experiments were conducted in the municipalities of Formosa-GO and Planaltina-DF, 2016/17 crop year. Both consisted of five precommercial maize hybrid platforms (HPA252, HPB262, HPB621, HPB646, and HPD354). Each platform consisted of three different versions: conventional, transgenic with a Bt gene that expresses the protein Cry $1 \mathrm{~F}$, and transgenic with two $\mathrm{Bt}$ genes that express the proteins Cry $1 \mathrm{~F}$ and CrylAB. The experiment was randomized blocks with four replications. The experimental plot was four lines five meters long considering the two central lines as useful. The lines were spaced 0.75 meters apart, and the final density was five plants per linear meter. To estimate grain yield, the plots were harvested, and the weight was extrapolated to kg.ha ${ }^{-1}$. The moisture was standardized at $14 \%$. Data were submitted to analysis of variance, and the means were compared by Tukey test at $5 \%$ probability using the Sisvar software. Grain yield between treatments ranged from 8,381 to $12,908 \mathrm{~kg} \cdot \mathrm{ha}^{-1}$, and the average yield was $11,234 \mathrm{~kg} \cdot \mathrm{ha}^{-1}$. The parameters evaluated were divided into two groups. The first group contained parameters determining grain yield: grain depth, thousand grains weight, number of rows of grains, number of grains per row, and grain yield. The second group contained morphoagronomic parameters that directly interfere with resistance to lodging and plant breaking: plant height, ear insertion height, and mean stem diameter. There was no direct effect of the transgenes on the evaluated hybrids since the classification of productivity was not divided into conventional and transgenic classes. It is suggested that the HPA252YH, HP621H and HP646H versions be discarded because grain yield performance was unsatisfactory compared to their respective conventional and transgenic counterparts. The parameters GD and W1000 are more effective for grain yield estimation than NR and NG. It was observed for HP621H that, in addition to a lower grain yield, there was a significant reduction in stem diameter, indicating a possible reduction in lodging tolerance and/or plant breaking when exposed to adverse climatic conditions such as windstorms. For the HPD354H version, the release of the transgenic counterpart HPD354YH is preferentially indicated since the $\mathrm{H}$ version had a significant reduction in stem diameter and a possible greater tolerance to lodging and/or plant breaking under the same conditions.
\end{abstract}

KEYWORDS: Spodoptera frugiperda. Transgenic events. Performance of grains. Plant lodging. Zea mays.

\section{INTRODUCTION}

Studies analyzing the efficacy of transgenic maize events that control Spodoptera frugiperda are often conducted as new transgenic events are studied and/or commercially released, both in Brazil and in other South American countries. Such studies aim to evaluate the effects of Bt proteins on larva control, genetic control of transgenic plants, and monitoring and efficiency of Bt (FERNANDES et al. 2010; MENDES et al. 2011).
In the last years, several researchers have published works in Brazil and in the world on this topic. Soon after the commercial release of the first transgenic $\mathrm{Bt}$ event that provides resistance to the fall armyworm, Fernandes et al. (2010) evaluated the effects of MON810 maize, which expresses the $\mathrm{Cry} 1 \mathrm{Ab}$ toxin, on $S$. frugiperda under field conditions and with a natural pest infestation during the 1999/2000 and 2000/2001 harvests. MON810 maize significantly reduces caterpillar infestation of $S$. frugiperda and the consequent damage to plants 
compared to conventional maize. The authors concluded that MON810 maize was effective in protecting the crop against infestations and damages by $S$. frugiperda. Araújo et al. (2011) observed that the transgenic maize hybrid P3041YG presented a lower damage caused by $S$. frugiperda, higher grain mass per ear, and higher grain yield in relation to the conventional hybrid.

Waquil et al. (2014) evaluated the efficacy of the pyramidal event MON 89034, which expresses the proteins Cry1A.105 and Cry2Ab2, for the control of Spodoptera frugiperda, Helicoverpa spp. and Diatraea saccharalis. The authors concluded that the pyramidal event is effective in the control of this lepidoptera-pest in maize crops.

Bedin et al. (2015) studied the efficacy of the maize hybrids CD316 (conventional), CD316 Herculex, CD316 PRO2, CD384 (conventional), CD384 Herculex, and CD384 Powercore. The authors found better results for the control of Spodoptera frugiperda by using CD316 PRO2 and CD384 Powercore. They determined that the hybrid CD384 Herculex was not effective against attacks of Spodoptera frugiperda.

When the efficacy of a transgenic event against a pest that causes economic impact is proven, the event is included into the genome of large-scale breeding programs. In maize, one way of introgression of transgenes is backcrossing. It consists of crossing the line to be converted with a donor line containing one or more transgenes of resistance to the target-insect. Afterwards, the backcrossing of this $F_{1}$ population is done with the recurrent lineage aiming to recover the original genome of the line being converted (MUMM, 2007; PEREIRA et al., 2008; CARNEIRO et al., 2009). This process, commonly called conversion of conventional into transgenic lineages, must be fast and cost-efficient. The lineages are improved in the program using technology, and this guarantees, besides the increase in genetic gain, the practicality of resistance to pests, thus forming the complete package that the market needs (STEWART JR; HALFHILL; WARWICK, 2003).

In order to meet the release of new transgenic hybrids in a timely manner, genetic breeding programs begin backcross conversions using molecular markers to monitor transgene maintenance and to verify the genome recovery of the recurrent parent at early stages, when the number of lineages can be quite high. Thus, it is guaranteed that the lineages that will be selected in the final stages of the program are converted and ready to be released. On the other hand, the number of lineages at this stage of the program is extremely high, and the conversion costs are directly proportional to the number of lineages being converted. Another factor that must be taken into account is that molecular analysis does not replace phenotypic selection in obtaining genotypes with a high grain yield. This is because grain yield is a quantitative and therefore polygenic characteristic greatly influenced by environmental conditions (TEIXEIRA et al., 2013).

The genetic effects that occur in the lineages when these events are inserted into the genome of the plant can be transferred to the hybrids composed by these lineages. Consequently, some rare adverse effects may negatively interfere with the permanence of undesirable alleles, undesirable phenotypes may appear, for example pleiotropic effects or toxins (GUERRA; NODARI, 2001). In addition to legal requirements, comparisons of agronomic characteristics that directly interfere with grain yield and other morpho-agronomic traits, such as tolerance to biotic and abiotic aspects, are little studied when an event is inserted into a lineage or into the hybrid. It is important to emphasize that hybrids bearing genes of interest, whether transgenes or not, will only be recommended as commercial hybrids if they present strong technological attributes and productivity levels equal to or higher than those already in the market. Therefore, studies aiming to determine the genetic interference of transgenic events with productivity, as well as the morpho-agronomic characteristics that influence yield, are of great relevance for society and for research. The objectives of this work are to determine phenotypic parameters that influence grain yield, compare genetically modified maize hybrids with conventional maize hybrids, and detect productivity variations due to the insertion of a single or double transgenic event.

\section{MATERIAL AND METHODS}

\section{Description of hybrids}

Pre-commercial

maize hybrids recommended for the central-north region of Brazil, named HPA252, HPB262, HPB621, HPB646 and HPD354, were analyzed in this study. These hybrids are under development for launching in the market with a high productive potential provided that a high technological level is used in crop conduction.

Maize hybrids present different cycles of physiological maturity. All of them are being developed for crops in the summer season. Superearly cycle (HPB646 and HPB621), early (HPB262 and HPA252) and normal cycle hybrids (HPA252) 
are described with a dual fitness for both grain production and silage production.

Because they are hybrids being developed for the Center-West region of Brazil, they should be well adapted to areas with an altitude above 800 meters in relation to the sea level. However, some hybrids achieved excellent grain yield results also in low altitude areas, such as HPB262, HPB646 and HPD354. Another important factor is disease tolerance. In this region of Brazil, the winter does not reach low temperatures; during the summer, the temperatures are very high and there are high rates of rainfall. Some of these products stand out because they tolerate polysorbate rust (Puccinia polysora), such as the hybrids HPA252 and HPB262. With regard to spot blotch (Exserohilum turcicum), another fungal leaf disease that commonly causes epidemics in this region, all products, with the exception of HPA252, have a good or very good tolerance. The hybrids HPA252, HPB262 and HPD354 are tolerant, the hybrid HPB621 is moderately tolerant, and the hybrid HPB621 is susceptible to white spot or phaeosphaeriae spot, a bacterial leaf disease caused by infection by Pantoea ananatis that is very aggressive in regions above 700 meters.

In addition to these leaf diseases, tolerance to the viral and molicute complex currently requires special attention. The hybrids in this study have a good tolerance to this complex, with the exception of HP621. This hybrid, despite being susceptible to two important diseases, has an extremely favorable range in different areas with good results for grain yield and adaptability. In addition, it has an excellent grain quality, a highly desirable characteristic that directly influences yield. All evaluated hybrids are highly tolerant to phytopathogenic fungi of grains such as giberella, diplodia and fusarium.

They all have an excellent grain quality. The hybrid HPD354 presents the best spectrum of tolerance to the mentioned diseases and to other relevant factors such as tolerance to late crops, and a high tolerance to breaking and lodging.

\section{Treatments}

The treatments were composed of five corn hybrids (HPA252, HPB262, HPB621, HPB646 and HPD354). Each hybrid has three different versions: a non-genetically modified, conventional (C); a TC1507 transgenic event expressing the protein Cry $1 \mathrm{~F}(\mathrm{H})$; and another transgenic version containing two MON810 and TC1507 events expressing two Bt proteins, Cry $1 \mathrm{Ab}$ and Cry $1 \mathrm{~F}(\mathrm{YH})$. These events provide resistance to some pest insects of maize crops, the most important of which is resistance to fall armyworm (S. frugiperda), a pest that causes the greatest economic damage to crops.

The intention of studying three versions of each hybrid and make a comparison within each version of the same hybrid, differing only by the insertion of transgenic events, is the detection of morphological and/or agronomic differences that interfere with determining parameters of grain yield. In this way, 15 treatments were used. The analyzes contemplated either each of the five hybrids or the set of five hybrids as long as they were classified as the same version referring to the presence or absence of transgenes.

\section{Description of the experimental area}

The experiment was conducted during the agricultural year 2016/17 on two commercial maize farms. One is located in Planaltina-DF and the other in the municipality of Formosa-GO. The first is located in an area with an altitude of 1,050 meters above sea level, and the other is located in an area at an altitude of 970 meters above sea level.

Both farms have a history of more than twenty years of agricultural cultivation. Both areas present a dystrophic red-yellow Latosol, and an annual average rainfall (at harvest), depending on the year, between 950 and 1,200 millimeters. Despite the small geographic distance between them (approximately fifty kilometers), the farm located in Planaltina focuses on the production of soybeans, maize and beans. The Formosa farm, besides soy, maize and beans, grows vegetables such as potatoes, garlic and carrots. The incidence of various leaf diseases is common in maize crops, and the virus complex causes epidemics with variable levels of severity. Another variable factor between the farms is the occurrence of storms and windstorms, which are very favorable for stem and root quality assessments, important factors for the determination of lodging and breaking tolerance.

\section{Experimental design}

The planting was carried out mechanically using an experimental planter of individual lines directly in the straw of commercial soybean crops. The experimental plots comprised four lines 4.3 meters long, and corridors of 0.7 meters separated them in the direction of planting. The interrow spacing was 0.75 meters. The plots were thinned when plants were at the vegetative stage V4 (four developed leaves) and 25 plants were kept. The final population of plants was 66 thousand plants per hectare. For data collection, only the two central lines of each plot were considered. 
The experimental design was randomized blocks with four replications. A $5 \times 3$ factorial design was used (five hybrids and three versions). Four applications of insecticides were made. At V2/V3, Metomil (800 $\mathrm{mL}^{-h^{-1}}$ ) was applied; at V5/V6 Espinosade was applied $\left(80 \mathrm{~mL} \cdot \mathrm{ha}^{-1}\right)$; and at V10, Chlorantraniliprole was applied $\left(110 \mathrm{~mL} \cdot \mathrm{ha}^{-1}\right)$. During pre-flowering, Espinosade was applied again $\left(80 \mathrm{~mL} \cdot \mathrm{ha}^{-1}\right)$.

These applications were made in order to control infestation by $S$. frugiperda larvae directed to conventional treatments and so that the larvae did not decrease the final plant stand. Two applications of fungicides were made with the intention of preventing infection by fungal leaf diseases. The mixture Picoxystrobin + Ciproconazole (400 mL.ha ${ }^{1}$ ) was applied during the pre-flowering period (first application). The second application was Tebuconazole $\left(1,000 \mathrm{~mL}^{-\mathrm{ha}^{-1}}\right)$ during postflowering, 20 days after the first application.

This management with insecticides and fungicides was carried out to reduce the effects of grain yield reduction due to pest attacks. Thus, it was possible to dramatically decrease experimental error and determine the genetic effects of transgene insertions not on control efficiency, but on grain yield.

\section{Measured morpho-agronomic characteristics}

Different agronomic parameters directly related to grain yield were evaluated, as well as morphological determinants for resistance to plant breaking and lodging. The evaluations were made after the full flowering period when the vegetative stage ended and after the reproductive stage began.

- Plant height (PLTHT/inches/in): four random plants from each experimental plot were measured, constituting a composite sample, and the mean was considered as one replicate per treatment;

- Ear insertion height (EARHT/inches/in): four random ears from each experimental plot were measured; they constituted a composite sample, and the mean was considered as one replication per treatment;

The agronomical parameters evaluated were:

- Number of rows per ear (NR): the number of rows of ten ears of random plants within each plot was determined (composite sample), and the mean was considered as one replicate per treatment;

- Number of grains per row (NG): one row of grains from ten ears of random plants within each plot was quantified (composite sample), and the mean was considered as one replicate per treatment;
- Grain depth (GD in millimeters): ten ears of random plants within each plot constituted a composite sample, and the mean was considered as one replicate per treatment. To obtain data of mean grain depths, the diameter of ears was determined; the diameter of corncobs after threshing was also determined, and the values of ear diameter minus the values of the corncob diameter were extrapolated, thus determining grain depth.

- Stem diameter (SD in millimeters): ten stems of random plants within each plot constituted a composite sample, and the mean was considered as one replicate per treatment.

- Ear diameter (SPKD in millimeters): ten ears of random plants within each plot constituted a composite sample, and the mean was considered as one replicate per treatment.

- Corncob diameter (CCD in millimeters): ten ears of random plants within each plot constituted a composite sample, and the mean was considered as one replicate per treatment.

- Thousand grains weight (W1000): formula based on the weight of one thousand seeds; eight sub-samples of 100 seeds were used according to the recommendations of the Rules for Seed Analysis (BRAZIL, 2009).

- Productivity (PROD): calculated based on the weight of the plot harvested, grain moisture at the time of harvest, and extrapolation to kg.ha- ${ }^{1}$ at a moisture adjusted to $14 \%$. The mechanical harvest occurred in a $7.5 \mathrm{~m}^{2}$ useful area using a specific harvester for four-line experiments. Production and grain moisture data at harvest were stored in an onboard computer.

\section{Statistical analysis}

Data were submitted to analysis of variance using the statistical software Sisvar (FERREIRA, 2011) by $F$ test, and the means of the treatments were compared by Tukey test at $5 \%$ probability for all characteristics evaluated.

For the most part, the parameters that determine productivity in a hybrid directly determine the genetic gain and the increase in productivity. For this, the study of associations between characters is of great importance in the field of genetic improvement of plants. This occurs likewise between the comparison of lineages or hybrids with distinct genetic backgrounds, or even with the same products, only differing from the insertion of transgenic events into their germplasm. 


\section{RESULTS AND DISCUSSION}

There was no statistically significant difference between both experiments conducted in the municipalities of Planaltina-DF and FormosaGO. It was thus possible to analyze data from the two farms together. In view of the results of grain yield, there was no grouping of hybrids with or without transgenic genes (Cry1F or Cry1F + Cry1AB) in the classification between the most productive and the least productive hybrids. Therefore, to determine the effects of the insertion of one or two Bt transgenic genes, the treatments were divided into five platforms. Each platform was represented by three versions, differing only by the presence of one (TC1507) or two (TC1507+ MON810) transgenic events expressing Bt proteins that provide resistance to Spodoptera frugiperda larvae.

The parameters evaluated were divided into two groups. The first group contained the parameters determining grain yield: grain depth (GD), thousand grains weight (W1000), number of rows of grains (NR), number of grains per row (NG), and grain yield (GY). The second group contained morpho-agronomic parameters that directly interfere with resistance to lodging and plant breaking: plant height $(\mathrm{PHe})$, ear insertion height (SH), and mean stem diameter (SD). Since grain production is the result of quantitative inheritance, many factors affect this variable, and its correlation with a single phenotypic characteristic is generally low. In addition, there is an interaction between the $\mathrm{Bt}$ event and the genotype affecting the insect response to larvae biomass and survival, leaf damage, and grain yield (WAQUIL et al., 2010).

\section{Grain yield}

Grain yield between treatments ranged from 8,381 to $12,908 \mathrm{~kg} \cdot \mathrm{ha}^{-1}$, and the average yield was $11,234 \mathrm{~kg} \cdot \mathrm{ha}^{-1}$. Five of the fifteen treatments were over 12,000 kg.ha- ${ }^{-1}$ (Table 1). This level of productivity corroborates with the reality of commercial upland maize crops in the Central-West region of Brazil ( 800 meters above sea level). Alves et al. (2015) evaluated the yield of 18 transgenic genotypes and obtained an average of $6,690 \mathrm{~kg} \cdot \mathrm{ha}^{-1}$. In the previous year, Alves et al. (2014) conducted an experiment comparing transgenic and conventional hybrids with early and super-early cycles, and obtained mean yields of 5,000 kg.ha- ${ }^{-1}$ and $5,920 \mathrm{~kg}^{-1}$, respectively. Both trials were conducted in the state of Rio Grande do Sul. Simon, Kamada and Moiteiro (2012) obtained better grain yield results. The authors tested 19 simple maize hybrids in the Midwest region (Rio Verde-GO city) during two seasons. In the 2007/2008 summer harvest, yields ranged from 7,928 to $10,712 \mathrm{~kg} \cdot \mathrm{ha}^{-1}$, and in the second half of 2008, the yield varied between 4,756 and $8,897 \mathrm{~kg} \cdot \mathrm{ha}^{-1}$.

Table 1. Means of productivity values of maize grains (GY) of 15 hybrids of conventional (C), transgenic containing the event TC1507 $(\mathrm{H})$, and transgenic containing the events TC1507 + MON810 (YH) hybrids.

\begin{tabular}{|c|c|c|c|}
\hline Hybrid & Version & \multicolumn{2}{|c|}{ GY $\left(\mathrm{kg.ha}^{-1}\right)$} \\
\hline HPB646 & $\mathrm{C}$ & $12,908.5$ & $\mathrm{a}$ \\
\hline HPB262 & $\mathrm{C}$ & $12,643.5$ & $\mathrm{ab}$ \\
\hline HPA252H & $\mathrm{H}$ & $12,393.1$ & $a b c$ \\
\hline HPB262YH & $\mathrm{YH}$ & $12,093.1$ & abcd \\
\hline HPA 252 & $\mathrm{C}$ & $12,022.1$ & abcd \\
\hline HPB646YH & $\mathrm{YH}$ & $11,969.6$ & abcd \\
\hline HPB262H & $\mathrm{H}$ & $11,901.6$ & abcd \\
\hline HPD354 & $\mathrm{C}$ & $11,359.5$ & abcde \\
\hline НРB646H & $\mathrm{H}$ & $11,253.2$ & abcde \\
\hline HPD354YH & YH & $10,783.8$ & bcde \\
\hline HPD354H & $\mathrm{H}$ & $10,780.7$ & bcde \\
\hline HPA252YH & YH & $10,423.5$ & cdef \\
\hline HPB621 & $\mathrm{C}$ & $10,101.1$ & def \\
\hline HPB621YH & YH & $9,508.1$ & ef \\
\hline HPB621H & $\mathrm{H}$ & $8,381.2$ & $\mathrm{f}$ \\
\hline Mean & & $11,234.8$ & \\
\hline CV (\%) & & 10.71 & \\
\hline
\end{tabular}

Brasília-DF, 2016.

Means followed by the same letter in the column do not differ significantly by Tukey test at $5 \%$ probability. 
Among the treatments evaluated, the most productive hybrid was the conventional HPB646, which produced $12,908.5 \mathrm{~kg} \cdot \mathrm{ha}^{-1}$. This hybrid was statistically different from the others. The hybrid HPB $621 \mathrm{H}$ was the least productive, reaching 8,381.2 kg.ha ${ }^{-1}$ of productivity. It also differed statistically from the others. For this hybrid, specifically, all three versions tested in this study were the least productive. This fact evidences that the effects of genotypes in these environments are a response to productivity, and not necessarily to the insertion of transgenic genes into their genome. It is important to note that productivity depends on factors related to the plant and its interactions with soil and climate conditions, which makes it vary significantly from one place to another (WAQUIL et al., 2014).

\section{Agronomic parameters determining productivity}

Of the five platforms of maize hybrids, there were statistical differences in three of them (HPA252, HPB262 and HPB646), and two of them were statistically equal as for grain yield (HPB262 and HPD354) (Table 2). Several studies on Bt maize genotypes compared to their conventional counterparts were conducted between 1994 and 2005 at universities in the United States and Canada. The Bt yields were higher according to these studies (NOLAN; SANTOS, 2012).

Table 2. Mean values of maize productivity: grain depth (GD), thousand grains weight (W1000), number of rows (NR), number of grains per row (NG), and grain yield (GY) of five maize hybrid platforms and three versions on each platform: conventional $(\mathrm{C})$, transgenic with the event TC1507 $(\mathrm{H})$, and transgenic with the events TC1507 + MON810 (YH).

\begin{tabular}{|c|c|c|c|c|c|}
\hline Hybrid & PG (mm) & $\mathrm{W} 1000(\mathrm{~g})$ & NR & $\mathrm{GF}^{* *}$ & GY $\left(\mathrm{kg} \cdot \mathrm{ha}^{-1}\right)$ \\
\hline HPA252 & $25.33 \mathrm{a}$ & $360 \mathrm{a}$ & $13.77 \mathrm{~b}$ & $39.70 \mathrm{a}$ & $12,022.12 \mathrm{a}$ \\
\hline HPA252H & $24.92 \mathrm{ab}$ & $347 \mathrm{ab}$ & $13.40 \mathrm{ab}$ & $38.85 \mathrm{a}$ & $12,393.12 \mathrm{a}$ \\
\hline HPA 252 YH & $23.68 \mathrm{~b}$ & $338 \quad \mathrm{~b}$ & $14.20 \mathrm{a}$ & $38.78 \mathrm{a}$ & $10,423.50 \quad b$ \\
\hline Mean & 24.65 & 348.92 & 13.79 & 39.11 & $11,612.91$ \\
\hline $\mathrm{CV}(\%)$ & 4.15 & 4.03 & 3.63 & 3.23 & 10.07 \\
\hline HPB262 & $24.55 \mathrm{a}$ & $314 \mathrm{a}$ & $16.92 \mathrm{a}$ & $35.87 \mathrm{~b}$ & $12,643.50 \mathrm{a}$ \\
\hline HPB262H & $24.35 \mathrm{a}$ & 309 a & $16.62 \mathrm{a}$ & $37.65 \mathrm{a}$ & $11,901.62 \mathrm{a}$ \\
\hline HPB262YH & $24.00 \mathrm{a}$ & $313 \mathrm{a}$ & $18.18 \mathrm{a}$ & $36.62 \mathrm{ab}$ & $12,093.12 \mathrm{a}$ \\
\hline Mean & 24.30 & 312.24 & 17.24 & 36.71 & $12,212.75$ \\
\hline $\mathrm{CV}(\%)$ & 4.87 & 3.65 & 14.82 & 2.72 & 5.81 \\
\hline HPB621 & $24.08 \mathrm{ab}$ & $304 a$ & $17.12 \mathrm{a}$ & $35.30 \mathrm{a}$ & $10,101.12 \mathrm{a}$ \\
\hline HPB621H & $23.45 \quad b$ & $291 \mathrm{a}$ & $17.17 \mathrm{a}$ & $35.55 \mathrm{a}$ & $8,381.25 \quad b$ \\
\hline HPB621YH & $24.50 \mathrm{a}$ & 299 a & $17.92 \mathrm{a}$ & $36.93 \mathrm{a}$ & $9,508.12 \quad \mathrm{a}$ \\
\hline Mean & 24.02 & 298.36 & 17.4 & 35.92 & $9,330.16$ \\
\hline $\mathrm{CV}(\%)$ & 3.24 & 4.23 & 11.54 & 4.52 & 8.24 \\
\hline HPB646 & $24.68 \mathrm{a}$ & $300 \mathrm{a}$ & $17.20 \mathrm{a}$ & $38.17 \mathrm{a}$ & $12,908.50 \mathrm{a}$ \\
\hline НРB646H & $24.07 \mathrm{ab}$ & $269 \mathrm{~b}$ & $17.27 \mathrm{a}$ & $36.95 \mathrm{a}$ & $11,253.25 \mathrm{~b}$ \\
\hline HPB646YH & $23.22 \mathrm{~b}$ & 289 a & $16.77 \mathrm{a}$ & $37.55 \mathrm{a}$ & $11,969.62 \mathrm{ab}$ \\
\hline Mean & 23.99 & 286 & 17.08 & 37.55 & $12,043.79$ \\
\hline $\mathrm{CV}(\%)$ & 4.25 & 4.49 & 3.25 & 4.02 & 8.29 \\
\hline HPD354 & $22.55 \mathrm{a}$ & $311 \mathrm{a}$ & $14.35 \mathrm{a}$ & $36.68 \mathrm{a}$ & $11,359.50 \mathrm{a}$ \\
\hline HPD354H & $22.13 \mathrm{a}$ & $295 \mathrm{ab}$ & $15.55 \mathrm{a}$ & $33.82 \mathrm{~b}$ & $10,780.75 \mathrm{a}$ \\
\hline HPD354YH & $22.42 \mathrm{a}$ & $280 \quad \mathrm{~b}$ & $16.21 \mathrm{a}$ & $36.65 \mathrm{a}$ & $10,783.87 \mathrm{a}$ \\
\hline Mean & 22.37 & 295.71 & 15.03 & 35.72 & $10,974.70$ \\
\hline $\mathrm{CV}(\%)$ & 3.75 & 7.02 & 17.36 & 3.16 & 5.84 \\
\hline
\end{tabular}

Brasília-DF, 2016.

Means followed by the same letter in the column do not differ significantly by Tukey test at 5\% probability.

Although the benefits of using Bt maize could be substantial in the presence of maize pests (RICE; PILCHER, 1998), field trials in the southeastern United States, without the presence of the pest, did not increase of productivity of transgenic genotypes compared to conventional genotypes when planted during the first planting dates (DELAMAR et al., 1999; BUNTIN et al., 2004; REAY-JONES; WIATRAK; GREENE, 2009; REAY-JONES; WIATRAK 2011). 
Subsequently, in trials planted one or two months after the recommended planting date, yield increase may be more frequent using $\mathrm{Bt}$ maize compared to conventional hybrids due to higher pest pressure (BUNTIN et al., 2001). With these findings, it is clear that the effects of increases in yield of the transgenic hybrids in these studies occurred due to the effects of the event, where there was no pest control. Chemical control with insecticides is necessary to control the pest in both $\mathrm{Bt}$ and conventional hybrids in order to quantify the genetic impact of the presence of transgenic events on grain yield (REAY-JONES; REISIG, 2014) (Table 2).

The most productive versions of the HPA252 platform were the $\mathrm{H}$ and the conventional version, with $12,393.12$ and $12,022.12 \mathrm{~kg} \cdot \mathrm{ha}^{-1}$, respectively. It was statistically different from the YH version, which produced only $10,423.50 \mathrm{~kg} \cdot \mathrm{ha}^{-1}$ (Table 1). When the parameters determining productivity were individually compared between versions within each platform, it was possible to identify which parameters were responsible for the decrease or increase in productivity. In the HPA252 platform, the parameters GD and W1000 of the YH version were statistically significant and lower than the other versions. NG did not differ statistically, but it was also lower. Therefore, even though the number of rows on average was higher, the other parameters together had a negative influence on grain yield of the $\mathrm{YH}$ version and consequently decreased the productivity by approximately $13 \%$ compared to the conventional version and by $16 \%$ compared to the $\mathrm{H}$ version (Table 2).

The most productive versions of the HPB621 platform were the conventional and $\mathrm{YH}$, with $10,101.12$ and 9,508.12 kg.ha ${ }^{-1}$, respectively. It was statistically different from the version $\mathrm{H}$, which produced only $8,381.25 \mathrm{~kg} \cdot \mathrm{ha}^{-1}$ (Table 2). As for the parameters individually compared, only grain depth was statistically different. The YH version had the highest depth, and did not differ from the conventional version. The other parameters did not differ statistically. However, numerically, the $\mathrm{YH}$ version was better for W1000, NR and NG than the $\mathrm{H}$ version. In addition, grain yield was $11 \%$ higher than the $\mathrm{H}$ version.

As for the HPB646 platform, the conventional version was the most productive, with $12,908.50 \mathrm{~kg} \cdot \mathrm{ha}^{-1}$, which did not differ from the YH, with $11,969.62 \mathrm{~kg} \cdot \mathrm{ha}^{-1}$, and differed from the $\mathrm{H}$ version, less productive, with $11,253.25 \mathrm{~kg} \mathrm{ha}^{-1}$ (Table 1). The $\mathrm{H}$ version of this platform was not different from the conventional version or the $\mathrm{YH}$ version. Between the two transgenic versions, the
YH version produced approximately $6 \%$ more than the $\mathrm{H}$ version. In this version, the thousand grains weight was statistically higher by 20 grams, and the number of grains per row was also higher, but not significantly. GD and NR were lower in the YH version, but not significantly (Table 2).

Simon, Kamada and Moiteiro (2012), studying genetic divergence among 19 maize hybrids, reported different agronomic and morphological parameters, and concluded that the characteristics that contributed the most to the explanation of the genetic divergence between the hybrids studied, both in crop and intercrop, were leaf area index, thousand grains weight, grain yield, number of grains per row, and number of rows of grains per ear.

The platforms HPB262 and HPD354 showed no statistical differences regarding grain yield. In both, the higher productivities were obtained by the conventional versions. However, the differences between the $\mathrm{H}$ and $\mathrm{YH}$ versions were minimal, less than $2 \%$ (Table 1). In the platform HPB262, the only parameter in which there was a statistically significant difference was the number of grains per row between the conventional version and the $\mathrm{H}$ version. The $\mathrm{H}$ version obtained a higher number of NG. In the platform HPD354, GD and NR showed no significant statistical differences. For $\mathrm{W} 1000$, the $\mathrm{H}$ version was not different from the $\mathrm{YH}$ version, but it was higher, since the number of grains per row of the $\mathrm{H}$ version was lower than the YH version. However, it did not interfere with the results, so that the productivities between versions were statistically different (Table 2).

\section{Morphological characteristics}

Among the platforms evaluated, there were no significant statistical differences between plant height $(\mathrm{PHe})$ and ear insertion $(\mathrm{SH})$ that could interfere with lodging resistance or plant breaking. According to Demétrio et al. (2008), the increase in the density of plants tends to increase the chances of breaking and/or lodging. There are differences between genotypes. Both Sangoi et al. (2002) and Argenta, Silva and Sangoi (2001) reported that plant height increases according to population density due to competition for light. Consequently, there is a stimulation of the apical dominance, which accelerates growth during the vegetative phase.

Some studies have reported discrepant results using different maize genotypes. Von Pinho et al. (2008) determined that an increase in density by 1,000 plants causes an increase by $0.20 \mathrm{~m}$ in plant height. Silva et al. (2008) reported that the increase by 10,000 plants $\mathrm{ha}^{-1}$ has increased PHe by 
$0.03 \mathrm{~m}$. Therefore, there is a considerable variation in response to population densities related to plant height, varying depending on the genetic material (VALLE et al., 2013). Santos et al. (2002) found a positive and significant correlation between maize grain yield, plant height and ear insertion, and reached an average yield of 7,071 kg.ha ${ }^{-1}$ in the Center-West region of Brazil.

There were significant statistical differences for the morphological trait stem diameter (SD) in the platforms HPB621 and HPD354. The YH version of the HPB621 platform obtained the largest stem diameter, followed by the conventional version and later by the $\mathrm{H}$ version, with a smaller diameter. This also occurred in the platform HPD354. The YH version obtained the largest stem diameter, followed by the conventional version and by the $\mathrm{H}$ version (Table 3).

Table 3. Mean values of morphological characteristics influencing maize bedding and plant breaking: plant height ( $\mathrm{PHe}$ ), ear insertion height (SH), and mean stem diameter (SD) of five maize hybrids and three versions in each platform: conventional $(\mathrm{C})$, transgenic containing the event TC1507 $(\mathrm{H})$, and transgenic containing the events TC1507+ MON810 (YH).

\begin{tabular}{|c|c|c|c|}
\hline Hybrid & PHe (cm) & SH (cm) & SD (mm) \\
\hline HPA252 & $275 \mathrm{a}$ & $156 \mathrm{a}$ & $27.42 \mathrm{a}$ \\
\hline HPA252H & 276 a & $155 \mathrm{a}$ & $27.47 \mathrm{a}$ \\
\hline HPA252YH & $277 \mathrm{a}$ & $152 \mathrm{a}$ & $29.20 \mathrm{a}$ \\
\hline Mean & 276.14 & 154.58 & 28.03 \\
\hline $\mathrm{CV}(\%)$ & 3.27 & 4.93 & 5.46 \\
\hline HP262 & $268 \mathrm{a}$ & $150 \mathrm{a}$ & $25.72 \mathrm{a}$ \\
\hline HP262H & $267 \mathrm{a}$ & $150 \mathrm{a}$ & $26.11 \mathrm{a}$ \\
\hline HP262YH & $262 \mathrm{a}$ & $150 \mathrm{a}$ & $24.75 \mathrm{a}$ \\
\hline Mean & 266.04 & 150.20 & 25.52 \\
\hline $\mathrm{CV}(\%)$ & 1.85 & 4.09 & 6.77 \\
\hline HP621 & $255 \mathrm{a}$ & $144 \mathrm{a}$ & $27.81 \mathrm{ab}$ \\
\hline HР621H & $259 \mathrm{a}$ & $144 \mathrm{a}$ & $26.42 \mathrm{~b}$ \\
\hline HP621YH & 259 a & $142 \mathrm{a}$ & $28.63 \mathrm{a}$ \\
\hline Mean & 258.12 & 143.85 & 27.62 \\
\hline $\mathrm{CV}(\%)$ & 2.83 & 3.68 & 4.30 \\
\hline HP646 & $272 \mathrm{a}$ & $152 \mathrm{a}$ & $27.35 \mathrm{a}$ \\
\hline НР646H & 274 a & $150 \mathrm{a}$ & $27.52 \mathrm{a}$ \\
\hline HР646YH & $278 \mathrm{a}$ & $149 \mathrm{a}$ & $27.32 \mathrm{a}$ \\
\hline Mean & 275.2 & 150.72 & 27.40 \\
\hline $\mathrm{CV}(\%)$ & 2.25 & 5.3 & 4.77 \\
\hline HPD354 & $262 \mathrm{a}$ & $145 \mathrm{a}$ & $28.66 \mathrm{ab}$ \\
\hline HPD354H & $260 \mathrm{a}$ & $140 \mathrm{a}$ & $27.65 \mathrm{~b}$ \\
\hline HPD354YH & $265 a$ & $143 \mathrm{a}$ & $29.60 \mathrm{a}$ \\
\hline Mean & 262.60 & 143.02 & 28.637 \\
\hline $\mathrm{CV}(\%)$ & 2.52 & 3.51 & 5.20 \\
\hline
\end{tabular}

Brasília-DF, 2016; Means followed by the same letter in the column do not differ significantly by Tukey test at 5\% probability.

According to Fancelli and Dourado Neto (2000), the stem is a very important structure for the plant both as a physical support to maintain the plant standing and for grain production, as it accumulates soluble solids that will be used later during the grain filling period.

RESUMO: Os objetivos foram estudar o comportamento de quinze híbridos pré-comerciais de milho, seus desempenhos agronômicos referentes à produtividade de grãos e os componentes diretos de produtividade, bem como suas características morfoagronômicas no Centro-Oeste do Brasil. Para tal, foram instalados dois experimentos nos municípios de Formosa-GO e Planaltina-DF no ano safra 2016/17, ambos constituídos por cinco plataformas de híbridos pré-comerciais de milho HPA252, HPB262, HPB621, HPB646 e HPD354. Cada 
plataforma foi constituída por três diferentes versões, convencional, transgênica que expressa à proteína Cry1 $\mathrm{F}$ e transgênica que expressa as proteínas Cry1F e Cry1AB. O delineamento experimental adotado foi de blocos casualizados com quatro repetições. A parcela experimental constituiu-se por quatro linhas de 5 metros, considerando-se úteis as duas linhas centrais. Estas, foram espaçadas de 0,75 metros e a densidade final foi de 5 plantas por metro. Após a colheita, os pesos das parcelas foram extrapolados para kg.ha ${ }^{-1}$ e a umidade foi padronizada em $14 \%$. Os dados foram submetidos à análise de variância e as médias foram comparadas pelo teste Tukey a 5\%, utilizando-se o software Sisvar. O rendimento de grãos variou entre 8.381 e 12.908 kg.ha ${ }^{-1} \mathrm{e}$ a produtividade média foi de $11.234 \mathrm{~kg} \cdot \mathrm{ha}^{-1}$. Os parâmetros avaliados foram divididos em dois grupos. Um com os parâmetros determinadores de produtividade de grãos, profundidade de grãos, peso de mil grãos, número de fileiras de grãos, número de grãos por fileira e produtividade de grãos e outro grupo dos parâmetros morfoagronômicos que interferem diretamente a resistência ao acamamento e quebramento de plantas, altura de plantas, altura de inserção de espiga e diâmetro médio de colmo. Não houve efeito direto dos transgenes nos híbridos avaliados em relação a produtividade de grãos. Sugere-se que as versões HPA252YH, HP621H e HP646H sejam descartadas, pois o desempenho de rendimento de grãos, quando comparados às suas respectivas contrapartes convencionais e transgênicas, foram insatisfatórias. Os parâmetros PG e P1000 mostraram-se mais efetivos para estimação de produtividade de grãos que NF e NG. Observou-se em HP621H, que além de menor produtividade de grãos, houve uma redução significativa do diâmetro de colmo, indicando uma possível redução da tolerância ao acamamento e/ou quebramento de plantas quando exposta a condições climáticas adversas como vendavais. Para a versão HPD354H, indica-se preferencialmente o lançamento da contraparte transgênica HPD354YH, pois a versão H teve uma redução significativa do diâmetro de colmo e também uma possível maior tolerância ao acamamento e/ou quebramento de plantas nas mesmas condições.

PALAVRAS-CHAVE: Spodoptera frugiperda. Eventos transgênicos. Rendimento de grãos. Acamamaento de plantas. Zea mays.

\section{REFERENCES}

ALVES, B. M.; CARGNELUTTI FILHO, A.; TOEBE, M.; BURIN, C.; DA SILVA, L. P. Variability of grain productivity and energy profile of maize (Zea mays L.) genotypes. Journal of Cereal Science, Pretoria, v. 60, n. 1, p. 164-171, 2014. https://doi.org/10.1016/j.jcs.2014.02.007

ALVES, B. M.; BURIN, C.; TOEBE, M.; DA SILVA, L. P. Divergência genética de milho transgênico em relação à produtividade de grãos e à qualidade nutricional. Ciência Rural, Santa Maria, v. 45, n. 5, p. 884-891, 2015. https://doi.org/10.1590/0103-8478cr20140471

ARAÚJO, L.; SILVA, A.; CRUZ, I.; CARMO, E.; NETO, A.; GOULART, M.; RATTES, J. FLUTUAÇÃO POPULACIONAL DE Spodoptera frugiperda, Diatraea saccharalis E Doru luteipes EM MILHO

CONVENCIONAL E TRANSGÊNICO. Revista Brasileira de Milho e Sorgo, Sete Lagoas, v. 10, n. 3, p. 205-214, 2011. https://doi.org/10.18512/1980-6477/rbms.v10n3p205-214

ARGENTA, G.; SILVA, P. R. F.; SANGOI, L. Arranjo de plantas em milho: análise do estado da arte. Ciência Rural, Santa Maria, v.31, n.5, p.1075-1084, 2001. https://doi.org/10.1590/S0103-84782001000600027

BRAZIL. Ministério da Agricultura Pecuária e Abastecimento. Rules for seed analysis-Regras para análises de sementes. MAPA, Brasília, DF. 399p. https://www.abrates.org.br/files/regras_analise_de_sementes.pdf.

BEDIN, F. A.; ASSMANN, E. J.; POLO, L. R. T.; SCHUSTER, I. Eficiência de eventos transgênicos de resistência a insetos em soja e milho. Revista Cultivando o Saber, Cascavel, v. 8, n. 2, p. 201-214, jun. 2015. Disponível em: https://www.fag.edu.br/upload/revista/cultivando_o_saber/55d1ef7ceb18d.pdf. Acesso em: 30 set. 2016.

BUNTIN, G. D.; LEE, R. D.; WILSON, D. M.; MCPHERSON, R. M. Evaluation of YieldGard transgenic resistance for control of fall armyworm and corn earworm (Lepidoptera: Noctuidae) on corn. Florida Entomologist, Gainesville, v. 84, n. 1, p. 37-42, 2001. https://doi.org/10.2307/3496660 
BUNTIN, G. D.; ALL, J. N.; LEE, R. D.; WILSON, D. M. Plant-incorporated Bacillus thuringiensis resistance for control of fall armyworm and corn earworm (Lepidoptera: Noctuidae) in corn. Journal of Economic Entomology, Indiana, v. 97, n. 5, p. 1603-1611, 2004. https://doi.org/10.1093/jee/97.2.259

CARNEIRO, A. A.; GUIMARÃES, C. T.; VALICENTE, F. H.; WAQUIL, J. M.; VASCONCELOS, M. J. V.; CARNEIRO, N. P.; MENDES, S. M. Milho Bt: teoria e prática da produção de plantas transgênicas resistentes a insetos-praga. Sete Lagoas: Embrapa Milho e Sorgo (Circular técnica, $\mathrm{N}^{\mathrm{o}}$ 135), 2009, 25 p.

DELAMAR, Z. D.; FLANDERS, K. L.; HOLLMAN, J. H.; MASK, P. L. Efficacy of transgenic corn against southern insect pests. In: Marion Junction, Arthropod Management Tests, Alabama, v. 24, n. 1, p. 417-418, 1999. https://doi.org/10.1093/amt/24.1.M8

DEMÉTRIO, C. S.; FORNASIERI FILHO, D.; CAZETTA, J. O.; CAZETTA, D. A. Desempenho de híbridos de milho submetidos a diferentes espaçamentos e densidades populacionais. Pesquisa Agropecuária Brasileira, Brasília, v. 43, n. 12, p. 1691-1697, 2008. https://doi.org/10.1590/S0100-204X2008001200008

FANCELli, A. L.; DOURADO NETO, D. Produção de milho. Guaíba: Agropecuária, 2000. 360 p.

FERNANDES, O. D.; PARRA, J. R. P.; NETO, A. F.; PÍCOLI, R.; BORGATTO, A. F.; DEMÉTRIO, C. G. B. EFEITO DO MILHO GENETICAMENTE MODIFICADO MON810 SOBRE A LAGARTA-DOCARTUCHO Spodoptera frugiperda (J. E. SMITH, 1797) (LEPIDOPTERA: NOCTUIDAE) Revista Brasileira de Milho e Sorgo, Sete Lagoas, v. 2, n. 2, p. 25-35, 2010. https://doi.org/10.18512/19806477/rbms.v2n2p25-35

FERREIRA, D. F. Sisvar: a computer statistical analysis system. Ciência e agrotecnologia, Lavras, v. 35, n. 6, p. 1039-1042, 2011. https://doi.org/10.1590/S1413-70542011000600001

GUERRA, M. P.; NODARI, R. O. Impactos ambientais das plantas transgênicas: as evidências e as incertezas. Agroecologia e Desenvolvimento Rural Sustentável, Porto Alegre v. 3, n. 3, p. 30-41, 2001.

MENDES, S. M; BOREGAS, K. G. B.; LOPES, M. E.; WAQUIL, M. S.; WAQUIL, J. M. Respostas da lagarta-do-cartucho a milho geneticamente modificado expressando a toxina Cry $1 \mathrm{~A}(\mathrm{~b})$. Pesquisa Agropecuária Brasileira, Brasília, v. 46, n. 3, p. 239-244, 2011. https://doi.org/10.1590/S0100204X2011000300003

MUMM, R. H. Backcross versus forward breeding in the development of transgenic maize hybrids: theory and practice. Crop science, Madison, v. 47, n. 3, p. 164-171, 2007.

https://doi.org/10.2135/cropsci2007.04.0014IPBS

NOLAN, E.; SANTOS, P. The contribution of genetic modification to changes in corn yield in the United States. American Journal of Agricultural Economics, Oxford, v. 94, n. 5, p. 1171-1188, 2012. https://doi.org/10.1093/ajae/aas069

PEREIRA, E. J. G.; STORER, N. P.; SIEGFRIED, BLAIR, D. Inheritance of Cry1F resistance in laboratoryselected European corn borer and its survival on transgenic corn expressing the Cry1F toxin. Bulletin of entomological research, Cambridge, v. 98, n. 6, p. 621-629, 2008.

https://doi.org/10.1017/S0007485308005920

REAY-JONES, F. P. F.; WIATRAK, P.; GREENE, J. K. Evaluating the performance of transgenic corn producing Bacillus thuringiensis toxins in South Carolina. Journal of Agricultural and Urban Entomology, Charleston, v. 26, n. 2, p. 77-86, 2009. https://doi.org/10.3954/1523-5475-26.2.77

REAY-JONES, F. P. F.; WIATRAK, P. Evaluation of new transgenic corn hybrids producing multiple Bacillus thuringiensis toxins in South Carolina. Journal of Entomological Science, Helen, v. 46, n. 2, p. 152-164, 2011. https://doi.org/10.18474/0749-8004-46.2.152 
REAY-JONES, F. P. F.; REISIG, D. D. Impact of corn earworm injury on yield of transgenic corn producing Bt toxins in the Carolinas. Journal of economic entomology, Indiana, v. 107, n. 3, p. 1101-1109, 2014. https://doi.org/10.1603/EC13516

RICE, M. E.; PILCHER, C. D. Potential benefits and limitations of transgenic Bt corn for management of the European corn borer (Lepidoptera: Crambidae). American Entomologist, Baltimor, v. 44, n. 2, p. 79-101, 1998. https://doi.org/10.1093/ae/44.2.75

SANGOI, L.; ALMEIDA, M. L. D.; SILVA, P. R. F. D.; RGENTA, G. Bases morfofisiológicas para maior tolerância dos híbridos modernos de milho a altas densidades de plantas. Bragantia, Campinas, v. 61, n. 2, p. 101-110, 2002. https://doi.org/10.1590/S0006-87052002000200003

SANTOS, P. G.; JULIATTI, F. C.; BUIATTI, A. L.; HAMAWAKI, O. T. Avaliação do desempenho agronômico de híbridos de milho em Uberlândia, MG. Pesquisa Agropecuária Brasileira, Brasília, v. 37, n. 5, p. 597-602, 2002. https://doi.org/10.1590/S0100-204X2002000500004

SILVA, A. G.; CUNHA JUNIOR, C. R.; ASSIS, R. L.; IMOLESI, A. S. Influência da população de plantas e do espaçamento entre linhas nos caracteres agronômicos do híbrido de milho P30K75 em Rio Verde, Goiás. Bioscience Journal, Uberlândia, v. 24, n. 2, p. 89-96, 2008.

SIMON, G. A.; KAMADA, T.; MOITEIRO, M. Divergência genética em milho de primeira e segunda safra. Semina: Ciências Agrárias, Londrina, v. 33, n. 2, p. 449-457, 2012. https://doi.org/10.5433/16790359.2012v33n2p449

STEWART JR, C. N.; HALFHILL, M. D.; WARWICK, S. I. Genetic modification: transgene introgression from genetically modified crops to their wild relatives. Nature Reviews Genetics, Londres, v. 4, n. 10, p. 806817, 2003. https://doi.org/10.1038/nrg1179

TEIXEIRA, F. F.; COSTA, F. M.; DE OLIVEIRA SÁBATO, E.; LEITE, C. E. P.; MEIRELLES, W. F.; GUIMARÃES, C. T.; BELICUAS, S. N. J. Pré-melhoramento de milho quanto à resistência a enfezamentos. Pesquisa Agropecuária Brasileira, Brasília, v. 48, n. 1, p. 51-58, 2013.

https://doi.org/10.1590/S0100-204X2013000100007

VALLE, Í. C. A.; ALVES, J. M. A.; DOS SANTOS SILVA, L.; UCHÔA, S. C. P.; ALBUQUERQUE, J. D. A. A.; DA SILVA, D. C. O. Produção do milho híbrido 30F35HR cultivado na savana de Roraima em diferentes densidades de plantio. Revista Agro@mbiente On-line, Boa Vista, v. 7, n. 3, p. 294-303, 2013. https://doi.org/10.18227/1982-8470ragro.v7i3.1543

VON PINHO, R. G.; GROSS, M. R.; STEOLA, A. G.; CRUZ MENDES, M. Adubação nitrogenada, densidade e espaçamento de híbridos de milho em sistema plantio direto na região sudeste do Tocantins. Bragantia, Campinas, v. 67, n. 3, p. 733-739, 2008. https://doi.org/10.1590/S000687052008000300023

WAQUIL, J. M.; VILLELA, F. M.; FERREIRA; FOSTER, JOHN E. Resistência do milho (Zea mays L.) transgênico (Bt) à lagarta-do-cartucho, Spodoptera frugiperda (Smith) (Lepidoptera: Noctuidae). Revista Brasileira de Milho e Sorgo, Sete Lagoas, v. 1, n. 3, p. 1-11, 2010. https://doi.org/10.18512/19806477/rbms.v1n3p1-11

WAQUIL, J. M.; DOURADO, P. M.; DE CARVALHO, R. A.; OLIVEIRA, W. S.; BERGER, G. U.; HEAD, G. P.; MARTINELLI, S. Manejo de lepidópteros-praga na cultura do milho com o evento Bt piramidado Cry1A. 105 e Cry2Ab2. Pesquisa Agropecuária Brasileira, Brasília, v. 48, n. 12, p. 1529-1537, 2014. https://doi.org/10.1590/S0100-204X2013001200001 